\title{
HUBUNGAN ANTARA TIPE KEPRIBADIAN MENURUT EYSENCK DENGAN KOMITMEN ORGANISASI PADA OSIS SMAN 2 CIMAHI
}

\author{
Asep Abdul Kadir, Fenti Hikmawati \& Witrin Gamayanti \\ Fakultas Psikologi UIN Sunan Gunung Djati Bandung, J1. A.H Nasution No. 105 Bandung \\ email: acodq86@gmail.com
}

\begin{abstract}
Abstrak
Penelitian ini berawal dari fenomena yang terjadi dalam sebuah organisasi siswa di sekolah, dimana aspek kerja sama antar anggotanya sangat diperlukan guna mencapai tujuan dari organisasi. Sebelum dapat saling bekerja sama, setiap individu itu tentunya harus memilki sebuah komitmen terhadap organisasinya. Peneliti memiliki asumsi bahwa tingkat komitmen yang dimiliki oleh masing-masing anggota organisasi berhubungan dengan tipe kepribadian yang dimilikinya. Eysenck (1974) mendefinisikan kepribadian sebagai hasil interaksi antara faktor bawaan dan pengaruh lingkungan dengan dasar pengkondisian respon, maka proses pembentukan kepribadian berlangsung dalam diri individu. Definisi komitmen terhadap organisasi menurut Porter (Schultz, 1982: 4) adalah suatu sikap individu yang memiliki kepercayaan dan penerimaan yang kuat atas tujuan dan nilai-nilai organisasi, kemauan untuk mengusahakan tercapainya kepentingan. Metode penelitian yang digunakan adalah metode korelasional. Berdasarkan hasil pengujian, diperoleh $\chi_{\text {hitung }}^{2}$ sebesar 5.013. $\chi_{\text {hitung }}^{2}$ tersebut kemudian dibandingkan dengan $\chi_{\text {tabel }}^{2}$ sebesar 3.84 (Siegel, 1997: 301). Karena harga $\chi_{\text {hitung }}^{2}=5.013$ lebih besar dari pada harga $\chi_{\text {tabel }}^{2}$ sebesar 3.84 pada taraf siginifikansi 0,05 , maka $\mathrm{H}_{0}$ ditolak. Dengan demikian dapat dikatakan bahwa terdapat hubungan antara Tipe Kepribadian dengan Komitmen Organisasi.
\end{abstract}

Kata kunci: kepribadian, extrovert, introvert, komitmen, organisasi

\section{Abstract}

This research based on phenomena of students council in which teamwork is really needed to get the organization goal. Before having teamwork, individu must have commitment to organization and level of commitment is assumed correlated with personality types. Eysenck (1974) defined personality as a result of interaction between inherited factors and surrounding. According to Porter (Schultz, 1982: 4), commitment on organization is individual attitude having trust and acceptance to the goal and values of organization. This research used correlational methodology. Result found $\chi 2$ hitung is 5.013 which is compared to $\chi 2$ tabel 3.84 (Siegel, 1997: 301). Since $\chi 2$ hitung $=5.013$ is more than $\chi 2$ tabel 3.84 on significant level 0,05, then Ho is not accepted. Therefore, it is concluded that there is correlation between personality type and organizational commitment.

Keywords : personality, extrovert, introvert, commitment, organization

\section{PENDAHULUAN}

Psikologi sebagai salah satu cabang dari ilmu pengetahuan, lahir karena rasa ingin tahu (curiousity) manusia terhadap dirinya sendiri. Rasa ingin tahu tersebut timbul karena manusia mulai mengamati dan menyadari adanya perbedaan yang sifatnya non-fisik antara ma- 
nusia yang satu dengan yang lainnya. Perbedaan-perbedaan tersebut terlihat jelas pada sifat, minat maupun perilaku antar tiap manusia, karena adanya berbagai perbedaan itulah para pemikir dan ilmuwan pada masa itu menggagas suatu ide tentang adanya suatu sistem dalam diri manusia yang mengatur dan menyebabkan perbedaan sifat dan perilaku pada manusia yaitu kepribadian (personality).

Eysenck (1974) sebagai salah tokoh psikologi pada saat itu, merumuskan bahwa kepribadian adalah suatu keseluruhan dari pola-pola tingkah laku yang tampil (terlihat) maupun tersembunyi (potensial) dalam diri individu yang ditentukan oleh faktor hereditas dan lingkungan, serta berkembang melalui interaksi fungsional antara faktor-faktor pembentuknya yaitu aspek: 1). Kognitif (intelligence) adalah suatu sistem tingkah laku kognitif yang relatif stabil dan berlangsung terus menerus, 2). Konatif (character) adalah suatu sistem tingkah laku konatif yang relatif stabil dan berlangsung terus menerus, 3). Afektif (temperament) adalah suatu sistem tingkah laku afektif atau emosi yang relatif stabil dan berlangsung terus menerus dan 4). Somatik (constitution) adalah suatu sistem konfigurasi tubuh atau neuendokrin yang relatif stabil dan berlangsung terus menerus. Dikarenakan adanya pengaruh faktor hereditas dan lingkungan, maka tidaklah dipungkiri bahwa kepribadian setiap manusia akan memiliki beberapa persamaan dan perbedaan.

Philip J. Corr (2009) mengemukakan bahwa keempat pola tingkah laku tersebut dirumuskan Eysenck berdasarkan dari beberapa hasil penelitian. Keempat pola tersebut sifatnya terstruktur dan saling berkaitan satu sama lain serta merupakan suatu kesimpulan dari hasil analisis dengan menggunakan metode analisis faktor.

Menurut Eysenck (1998), metode analisis faktor adalah suatu metode analisis guna menemukan variabel terkecil yang sifatnya independen, yang dapat menggambarkan dan mengklasifikasikan suatu mental ability dan trait dari suatu temperamen, semua hal itu tiada lain untuk menjelaskan keterkaitan dari semua hasil eksperimen yang telah dilakukan sampai saat ini. Dengan kata lain, Eysenck (1998) pada saat itu masih berusaha untuk mencari dan menemukan berbagai variabel lain yang dapat berguna sebagai tambahan informasi dalam merumuskan teori kepribadian dan mengungkap keterkaitan antara variabel yang satu dengan variabel yang lainnya.

Eysenck (1997) berpendapat bahwa kepribadian individu tersusun atas tindakan-tindakan, disposisi-disposisi yang terorganisasi dalam susunan hierarki berdasarkan atas tingkat keumuman dan kepentingannya. Eysenck (1997) berpendapat bahwa kepribadian terdiri atas reaksi-reaksi, respon-respon dan tingkah laku dari yang sifatnya paling khusus dan rendah ke yang paling umum dan tinggi, yaitu sebagai berikut: 1). Specific response, merupakan tingkatan terendah dalam herarki struktur kepribadian Eysenck. Specific response yaitu tindakan atau respon yang terjadi pada suatu keadaan atau kejadian tertentu. 2). Habitual response. Habitual response merupakan tingkatan kedua, habitual response mempunyai corak yang lebih umum dari specific response. Habitual response dapat diartikan respon-respon yang berulang-ulang terjadi jika individu menghadapi situasi atau kondisi yang sejenis. 3). Trait, berada pada tingkat ketiga. Trait sendiri yaitu habitual response yang paling berhubungan satu sama lain dan cenderung ada pada individu tertentu. 4). Type, merupakan level tertinggi atau berada pada tingkatan keempat pada struk-tur kepribadian Eysenck. Type yaitu organisasi sifat di dalam diri individu yang lebih umum dan menunjukkan adanya sistem saling keterkaitan antara trait-trait yang ada pada individu tersebut.

Lebih lanjut, Eysenck (1970) merumuskan beberapa dimensi dari kepribadian manusia. Dimensi-dimensi kepribadian itu diantaranya dimensi extovert-introvert, stable-unstable emotion), psychoticism dan phlegmatic sanguine serta choleric - melancholi. Hadirnya dimensi-dimensi kepribadian tersebut secara tidak langsung menandakan adanya suatu perbedaan reaksi-reaksi manusia terhadap berbagai stimulus yang berasal dari lingkungannya terutama lingkungan sosialnya.

Dalam menguraikan dimensi kepribadian ekstrovert-introvert, Eysenck (1997) memberikan beberapa karakteristik atau ciri-ciri dari suatu individu yang berada pada dimensi tersebut. Ia menyatakan bahwa "individu dengan tipe kepribadian extrovert memiliki karakteristik antara lain cenderung kurang peka terhadap perasaan orang lain (touch restless), memiliki banyak teman (sociable), membutuhkan orang untuk diajak berbicara (talkative), tidak menyukai membaca dan belajar sendiri, 
mencari-cari kegembiraan (sensation seeking), mudah tertarik terhadap sesuatu yang baru (exciteable), mudah berubah (changeable)........" (Eysenck, 1997: 19).

Karakteristik individu dengan kecenderungan introvert antara lain tergantung suasana hati (moody), cemas (anxious), kaku (rigid), tenang (calm), pemalu (shy), lebih suka menyendiri (reserved), introspektif (thougtful), lebih menyukai buku/membaca daripada berbicara dengan orang lain dan menghadapi persoalan sehari-hari dengan serius, bersikap hati-hati dan menjaga jarak kecuali dengan teman dekatnya (careful)..........." (Eysenck, 1997: 19).

Lebih jauh lagi Eysenck (dalam Dewi, 2008: 27) menggambarkan dimensi extrovert dan introvert sebagai berikut: 1). Extrovert introvert merupakan kecenderungan untuk bertingkah laku dari seseorang sebagai akibat adanya proses penyerapan terhadap segala sesuatu yang ada dilingkungan, selanjutnya akan tampak jelas saat individu bertingkah laku dalam situasi yang berbeda-beda. 2). Kecenderungan extrovert - introvert sudah terlihat pada masa nak-anak yang selanjutnya akan berkembang menjadi karakteristik kepribadian individu. 3). Perbedaan individu dalam extrovert - introvert ada dalam suatu garis kontinum. Artinya ciri khas individu bisa dilihat dari kedudukan individu pada garis kontinum tersebut.

Kepribadian manusia terbentuk tidak hanya berasal dari faktor keturunan (herediter) saja, akan tetapi juga terbentuk dari faktor luar yaitu berupa lingkungan. Lingkungan sebagai salah satu faktor pembentuk kepribadian (personality) merupakan tempat bagi suatu individu untuk mengenal, memahami dan belajar untuk membentuk kepribadiannya, baik itu dalam lingkungan rumah, sekolah, masyarakat atau bahkan organisasi.

Khususnya dalam lingkungan organisasi, setiap individu akan benar-benar berinteraksi dengan lingkungan nyata yang menuntutnya untuk dapat memberikan kontribusi kepada organisasi tersebut sesuai dengan tujuan yang telah ditetapkan. Hal ini sesuai dengan yang dinyatakan oleh Schermerhon bahwa "organisasi merupakan kumpulan dari 2 atau lebih individu yang saling berinteraksi dan mempunyai tujuan dan aturan bersama" (Nelson dan Cooper (ed), 2007: 64).

Organisasi sebagai sebuah perkumpulan yang bertujuan untuk mencapai satu tujuan, dalam upayanya tentu membutuhkan kesunggu- han atau sebuah komitmen dari setiap anggotanya. Komitmen tersebut berfungsi sebagai 'perekat' antara organisasi dengan setiap anggotanya. Apabila sebuah organisasi dipenuhi oleh sejumlah anggota yang tidak memiliki komitmen organisasi, maka organisasi itu akan rentan sekali mengalami kemandegan, melenceng dari tujuan semula atau bahkan mengalami kemunduran.

Porter (1974) memberikan definisi tentang komitmen organisasi melalui pernyataannya bahwa komitmen organisasi adalah suatu keyakinan tertentu dan penerimaan terhadap nilai-nilai dan tujuan-tujuan organisasi, kemauan dan usaha yang tinggi untuk organisasi, keinginan yang kuat untuk tetap menjadi anggota dalam suatu organisasi (dalam Schultz, 1982: 3)

Porter (1974) menjelaskan bahwa seseorang yang memiliki komitmen terhadap organisasi maka ia haruslah memiliki keyakinan dan mampu menerima nilai-nilai serta tujuantujuan organisasi (Schultz, 1982: 3). Seseorang yang telah tergabung dalam suatu organisasi maka secara tidak langsung ia pun akan berhadapan dengan nilai-nilai dalam organisasi tersebut, baik itu nilai dalam berinteraksi dengan orang lain maupun nilai-nilai dalam melaksanakan tugasnya sebagai anggota dari organisasi tersebut.

Selanjutnya ia pun menjelaskan bahwa seseorang yang memiliki komitmen terhadap organisasi maka ia akan memiliki kemauan dan usaha yang tinggi untuk organisasi. Kemauan dan usaha yang dimaksud adalah kemauan dalam melaksanakan tugas-tugasnya sebagai anggota organisasi. Sedangkan yang dimaksud dengan usaha yang tinggi adalah suatu totalitas dari anggota dalam melaksanakan tugas-tugas yang telah dirancang sebelumnya.

Adapun yang dimaksud dengan adamya keinginan yang kuat untuk tetap menjadi anggota dalam suatu organisasi yaitu bahwa setiap anggota yang memiliki suatu komitmen terhadap organisasi, maka anggota tersebut akan senantiasa untuk terus berusaha agar ia tetap menjadi bagian dalam organsiasi tersebut, baik secara administratif, formal maupun non-formal. Anggota yang memiliki komitmen maka secara formal ia akan mengikuti setiap aturan yang ada dalam organisasinya baik itu dalam hal pengisian absen, pembuatan kartu anggota maupun kelengkapan semua data administrasinya. Secara non-formal, anggota yang memiliki komitmen organisasi maka ia akan senan- 
tiasa berusaha untuk tetap berinteraksi serta menjaga hubungan baik dengan sesama anggota yang ada dalam organisasi tersebut.

Tingkat komitmen organisasi suatu anggota sangat dipengaruhi oleh beberapa faktor, Steer dan Porters (1987) menyatakan bahwa salah satu faktor yang mempengaruhi komitmen organisasi adalah karakteristik individu. Berdasarkan hasil penelitian yang telah ia lakukan, diketahui bahwa karakteristik individu seperti usia, motif dan tipe kepribadian mempengaruhi komitmen anggota terhadap organisasi.

Khususnya dalam tipe kepribadian, jika peneliti mengacu kepada teori tipe kepribadian yang dinyatakan oleh Eysenck (1998) bahwa terdapat dua macam tipe kepribadian yaitu ekstrovert dan introvert, maka peneliti berasumsi bahwa individu dengan kecenderungan ekstrovert seharusnya memiliki tingkat komitmen organisasi yang lebih tinggi daripada individu dengan kecenderungan introvert. Hal itu tiada lain karena individu dengan kecenderungan ekstrovert akan lebih mudah bersosialisasi dan menemukan kenyamanan dalam organisasi karena mereka memiliki karakteristik mudah bergaul, optimis, membutuhkan banyak teman, periang dan suka bercanda.

Individu dengan kepribadian ekstrovert akan cenderung lebih memiliki komitmen organisasi yang tinggi disebabkan individu tersebut akan lebih mudah beradaptasi terhadap lingkungannya. Hal tersebut sesuai dengan yang dikatakan oleh Eysecnk (McCroskey dan Wahba, 2005: 158) bahwa individu ekstrovert lebih mudah untuk bersosialisasi, asertif dan objektif. Ketika ia mudah beradaptasi maka ia akan lebih mudah untuk tetap menjadi anggota dalam organisasi tersebut.

Hal tersebut sesuai dengan yang dinyatakan oleh Meyer dan Allen bahwa komitmen terhadap suatu organisasi akan timbul apabila anggota dalam organisasi tersebut memiliki keterikatan psikologis dengan organisasinya. Keterikatan psikologis tersebut muncul dan berkembang karena adanya dorongan rasa kenyamanan, keamanan, dan manfaat lain yang dirasakan dalam suatu organisasi yang tidak diperolehnya dari tempat atau organisasi yang lain. Semakin nyaman dan tinggi manfaatnya yang dirasakan oleh anggota, semakin tinggi komitmen seseorang pada organisasi (Schultz, 1982: 3).
Sebaliknya, individu dengan kecenderungan introvert seharusnya memiliki tingkat komitmen organisasi yang rendah, hal tersebut dikarenakan individu dengan kecenderungan introvert yang memiliki karakteristik pasif, menyukai kesendirian, pesimistis, selalu menjaga jarak dan tidak menyukai keramaian akan lebih sukar untuk menemukan kenyamanan dalam suatu organisasi karena mereka memiliki hambatan dalam bersosialisasi dan bekerja sama dengan teman-temannya dalam satu organisasi.

Akan tetapi peneliti mendapatkan suatu fenomena yang berbeda di lapangan, yaitu adanya beberapa anggota dari suatu organisasi dengan tipe kepribadian cenderung introvert memiliki tingkat komitmen organisasi yang tinggi. Fenomena tersebut peneliti temukan pada pengurus OSIS SMAN 2 Cimahi.

Berdasarkan hasil wawancara dengan ketua OSIS, dapat diketahui bahwa organisasi ini memiliki pengurus berjumlah 51 orang yang terdiri dari kelas $X$ sejumlah 25 orang dan kelas X1 26 orang. Dari 51 pengurus tersebut, yang dapat dikatakan masih aktif mengikuti rapat dan berkontribusi dalam setiap programprogram yang diselenggarakan hanyalah sekitar 15 orang saja. Sedangkan pengurus lain yang berjumlah 36 orang dapat dikatakan sudah jarang atau bahkan tidak aktif dan berkontribusi lagi terhadap organisasinya.

Selain data tersebut, peneliti pun mendapatkan keterangan tentang karakteristik kepribadian pengurus OSIS yang masih aktif dan dapat dikatakan memiliki komitmen tinggi terhadap organisasinya. Mereka yang masih aktif dan memiliki komitmen tinggi memiliki sifat yang periang, mudah bergaul, tekun, rata-rata memiliki prestasi bagus dalam bidang akademik, kalem, aktif dan banyak melakukan kegiatan, tetapi dari mereka ada juga yang memiliki sifat pemalu, mudah terbawa emosi, pesimis dan penyendiri.

Selain data yang diperoleh dari ketua OSIS, peneliti juga mendapatkan data sementara yang didapatkan dari hasil wawancara dengan pembina OSIS SMAN 2 Cimahi, beliau menyatakan bahwa pada masa awal dibentuknya pengurus OSIS angkatan ini, OSIS ini mempunyai pengurus yang terdiri dari berbagai karakter, ada yang sopan, rajin, pandai bicara, supel, taat pada aturan melaksanakan setiap tugas-tugasnya. Tetapi ada juga pengurus yang hanya mengutarakan konsep tetapi pada 
waktu pelaksanaan dia tidak ada, ada yang pendiam, malu-malu, mudah menyerah ketika di beri tugas, kemudian tidak mudah bergaul. Setelah beberapa bulan berlalu, sampai saat ini pengurus yang tersisa sekarang secara keseluruhan karakternya lebih banyak yang pandai bergaul, punya banyak teman, mau bekerja dan tentunya mau bekerjasama dengan pengu-rus yang lain, meskipun memang ada juga sih beberapa orang yang punya karakter malu-malu, penyendiri, atau bisa juga di bilang kurang percaya diri, tetapi ia masih tetap bertahan di OSIS dan bisa bekerjasama dengan yang lain.

Selain gambaran kepribadian dari pengurus yang masih aktif, peneliti pun mendapatkan gambaran tentang kepribadian pengurus yang sudah tidak aktif atau memiliki komitmen rendah. Mereka yang sudah tidak aktif menjadi pengurus OSIS memiliki kepribadian yang pasif, kurang inisiatif dalam melaksanakan program, menyukai bercanda akan tetapi mudah tersinggung, lebih mementingkan nilai akademik atau organisasi lain, merasa minder, mudah bosan, dan cenderung kurang mampu mengeluarkan gagasan-gagasan.

Selain data tentang gambaran tipe kepribadian, peneliti juga melakukan wawancara untuk mengetahui alasan bagi mereka yang masih aktif dan yang sudah tidak aktif. Alasan bagi mereka yang masih aktif (memiliki komitmen tinggi) adalah karena mereka merasa memiliki tanggung jawab dan berusaha untuk memegang amanah, merasa nyaman dengan pengurus yang lain (sudah bagaikan keluarga), tidak ada kesibukan yang lain, mencari pengalaman, memiliki posisi penting di OSIS.

Sedangkan alasan bagi mereka yang sudah tidak aktif atau lebih memilih untuk keluar dari OSIS dikarenakan adanya larangan dari orang tua mereka, adanya ketidakcocokan dengan pengurus yang lain, merasa hanya menjadi 'pesuruh' (terintimidasi) oleh pengurus lain, gagasan-gagasan mereka yang selalu ditolak, merasa lebih dihargai di organisasi lain, merasa tidak cocok dengan lingkungan pergaulan di OSIS dan merasa kecewa dengan pimpinan OSIS.

Berdasarkan berbagai keterangan tersebut, peneliti tentunya mendapatkan berbagai data tambahan yang memperkuat adanya fenomena bahwa tidak hanya individu dengan kecenderungan ekstrovert saja yang memiliki tingkat komitmen terhadap organisasi yang tinggi, akan tetapi juga ada beberapa individu de- ngan kecenderungan introvert, yang memiliki tingkat komitmen organisasi yang tinggi pula.

\section{METODE PENELITIAN}

Metode yang digunakan dalam penelitian ini adalah metode kuantitatif, dengan menggunakan metode korelasional, yaitu sebuah penelitian yang bertujuan untuk menemukan ada tidaknya hubungan dari dua variabel dan untuk melihat derajat keeratan hubungan kedua variabel tersebut.

Variabel pertama yang terdapat dalam penelitian ini adalah kepribadian, Eysenck (1974) mendefinisikan kepribadian sebagai hasil interaksi antara faktor bawaan dan pengaruh lingkungan dengan dasar pengkondisian respon, maka proses pembentukan kepribadian berlangsung dalam diri individu. Variabel kedua yaitu komitmen terhadap organisasi, Porter (Schultz, 1982: 4) mendefinisikannya sebagai sikap individu yang memiliki kepercayaan dan penerimaan yang kuat atas tujuan dan nilai-nilai organisasi, kemauan untuk mengusahakan tercapainya kepentingan organisasi, dan keinginan yang kuat untuk mempertahankan keanggotaan organisasi

Populasi dalam penelitian ini berjumlah 40 orang anggota OSIS SMAN 2 Cimahi yang terdaftar dan aktif mengikuti kegiatan. Untuk menguji hipotesis utama, maka perhitungan statistik yang digunakan dalam penelitian ini adalah uji Koefisien Kontingensi $C$ untuk dua sampel independen, ini digunakan untuk mengukur asosiasi atau relasi yang menuntut kedua variabel yang diukur sekurang-kurangnya dalam skala nominal (Siegel, 1997).

\section{HASIL DAN PEMBAHASAN}

\section{Hasil}

Dengan melihat kriteria pengujian bahwa $\chi_{\text {hiung }}^{2}>\chi_{\text {tabel }}^{2}$ berarti $\mathrm{H}_{0}$ ditolak dan $\mathrm{H}_{1}$ diterima, maka dari hasil analisa menunjukkan adanya hubungan antara tipe kepribadian dengan komitmen organisasi pada pengurus OSIS SMAN 2 Cimahi, karena $\chi_{\text {hiung }}^{2}=5.013$ dan $\chi_{\text {tabel }}^{2}=3,84$ dengan $\mathrm{df}=1$ dan $=0,05$. Dengan demikian terdapat hubungan positif antara tipe kepribadian dengan komitmen organisasi pada pengurus OSIS SMAN 2 Cimahi. Dengan kata lain, jika siswa memiliki tipe kepribadian cenderung extrovert maka ada kecenderungan un- 
tuk memiliki tingkat komitmen organisasi yang lebih tinggi, dan jika siswa memiliki tipe kepribadian introvert maka ada kecenderungan untuk memiliki tingkat komitmen organisasi yang lebih rendah.

Untuk mengetahui derajat asosiasi antar variabel, dilakukan perhitungan koefisien $\mathrm{C}$ dan kemudian membandingkannya dengan nilai Cmax. Dengan nilai $\mathrm{C}=0,338$ dan $\mathrm{Cmax}=$ 0.707 maka korelasi antara tipe kepribadian dan komitmen organisasi tersebut termasuk dalam derajat asosiasi antar variabel korelasi sedang yaitu: 0,4 Cmax < $\mathrm{C}<0,6 \mathrm{Cmax}$ atau harga $\mathrm{C}$ berada pada kriteria $0,2828<\mathrm{C}<$ 0,4242 . Hasil tersebut memiliki arti bahwa sebagian besar siswa yang memiliki tipe kepribadian ekstrovert memiliki tingkat komitmen organisasi yang tinggi, demikian pula sebaliknya, sebagian besar siswa yang memiliki tipe kepribadian introvert memiliki tingkat komitmen organisasi yang rendah.

Berdasarkan hasil analisis deskriptif dapat diketahui bahwa subjek yang memiliki tipe kepribadian cenderung ekstrovert dengan komitmen organisasi rendah sebanyak 5 orang atau $12.5 \%$ dari 17 orang siswa dengan kecenderungan memiliki kepribadian ekstrovert, dan subjek yang memiliki kecenderungan kepribadian introvert dengan komitmen organisasi rendah sebanyak 15 orang atau $37.5 \%$ dari 23 orang yang memiliki kecenderungan introvert.

Sedangkan subjek dengan tipe kecenderungan ekstrovert dengan komitmen organisasi tinggi sebanyak 12 orang atau $30 \%$ dari 17 orang siswa dengan kecenderungan ekstrovert, dan subjek yang memiliki kecenderungan kepribadian introvert dengan komitmen organisasi tinggi sebanyak 8 orang atau $20 \%$ dari 23 orang dengan kecenderungan introvert.

\section{Pembahasan}

Berdasarkan hasil pengujian diketahui bahwa tingkat asosiasi antar variabel berada pada derajat sedang dapat diartikan bahwa masih terdapat faktor-faktor lain selain tipe kepribadian ekstrovert-introvert, yang lebih memiliki hubungan dan mempengaruhi komitmen organisasi pada subjek. Terdapatnya faktorfaktor lain tersebut, terlihat pada hasil analisis deskriptif, yaitu adanya data yang menunjukkan subjek dengan kecenderungan ekstrovert yang memiliki tingkat komitmen organisasi rendah dan terdapat pula subjek dengan kecen- derungan introvert yang memiliki tingkat komitmen organisasi tinggi.

Berdasarkan hasil interview dan observasi yang peneliti lakukan pada pengurus SMAN 2 Cimahi, peneliti mendapatkan gambaran bahwa faktor-faktor tersebut yaitu: kurangnya penghargaan terhadap anggota, tidak tercapainya kebutuhan akan harga diri, kurangnya dukungan orang tua terhadap anaknya untuk berorganisasi dll. Untuk lebih jelasnya, peneliti akan jabarkan analisa sebagai berikut:

Subjek dengan kecenderungan kepribadian ekstrovert yang memiliki komitmen organisasi tinggi

Dalam penelitian ini terdapat $30 \%$ subjek dengan kecenderungan kepribadian ekstrovert yang memiliki komitmen organisasi tinggi. Hasil ini tentunya sesuai dengan alur pemikiran dan hipotesis awal peneliti, yakni seseorang dengan tipe kepribadian cenderung ekstrovert tentunya dapat lebih fleksibel dalam berinteraksi, pandai bersosialisasi dan objektif dalam berpikir.

Hal tersebut sesuai dengan pernyataan Eysenck (1998), yaitu bahwa :

..(a) the introvert has a more subjective, the extravert a more objective outlook; (b) the introvert shows a higherdegree of cerebral activity, the extravert a higher degree of behavioural activity; (c) the introvert shows a tendency to self-control (inhibition), the extravert a tendency to lack of such control.

Dari penyataan diatas dapat diambil beberapa poin yaitu bahwa seseorang dengan kecenderungan introvert lebih berpikir subjektif dan ekstrovert lebih objektif, hal tersebut tentu saja sangat berpengaruh besar terhadap komitmen organisasi. Seseorang yang berpikiran subjektif akan relatif lebih sukar untuk berbaur dan bergaul dengan suatu kelompok karena ia kurang dapat membedakan mana hal-hal yang sifatnya pribadi dan mana hal-hal yang sifatnya kepentingan bersama. Selain itu bagi seseorang subjektif maka ia akan lebih banyak mengalami ketakutan-ketakutan yang belum tentu benar kebenarannya, contohnya takut salah, takut dijauhi oleh teman-temannya, takut gagal dll. Hal tersebut akan lebih bertambah parah apabila ia tidak memiliki sifat asertif sehingga ia tidak mampu untuk mengungkapkan perasaan-perasaannya tersebut.

Sebaliknya seseorang dengan kecenderungan ekstrovert yang memiliki cara berpikir objektif, maka ia akan relatif memandang su- 
atu permasalahan secara objektif, mampu membedakan kapan waktunya untuk bekerja dan bercanda, tahu kelebihan dan kekurangannya serta mampu mendudukkan permasalahan menurut porsinya.

Ketika seseorang memiliki kemampuan untuk berpikir objektif, maka secara tidak langsung ia akan memiliki tingkat komitmen yang lebih tinggi. Hal itu tiada lain karena ia akan dapat menjaga proses komunikasi, serta menjaga hubungan pergaulannya dengan teman-temannya di dalam suatu organisasi. Hal tersebut sesuai dengan apa yang dinyatakan oleh Meyer dan Allen (Schultz, 1982: 3) yaitu bahwa komitmen organisasi akan timbul berdasarkan tingkat keterikatan secara psikologis dengan organisasi berdasarkan seberapa baik perasaan mengenai organisasi. Komitmen ini muncul dan berkembang oleh dorongan adanya kenyamanan, keamanan, dan manfaat lain yang dirasakan dalam suatu organisasi yang tidak diperolehnya dari tempat atau organisasi yang lain. Semakin nyaman dan tinggi manfaatnya yang dirasakan oleh anggota, semakin tinggi komitmen seseorang pada organisasi.

Kenyamanan psikologis dalam suatu organisasi memang menjadi salah satu faktor dari adanya komitmen terhadap organisasi tersebut. Jika kita kembali melihat pernyataan Schermerhon (dalam Ashkanasy, 2007: 64) bahwa "organisasi merupakan kumpulan dari 2 atau lebih individu yang saling berinteraksi dan mempunyai tujuan dan aturan bersama". Berdasarkan pernyataannya tersebut dapat peneliti simpulkan bahwa dengan interaksi yang baik maka akan dapat menimbulkan komitmen seseorang terhadap suatu organisasi sebaliknya jika seseorang mengalami hambatan dalam interaksinya maka ia akan mengalami hambatan pula dalam memiliki komitmen terhadap organisasinya.

Berdasarkan hal tersebut, jika peneliti kaitkan dengan pernyataan Eysenck (1997) mengenai karakteristik ekstrovert antara lain adalah ".......memiliki banyak teman (sociable), membutuhkan orang untuk diajak berbicara (talkaktive), tidak menyukai membaca dan belajar sendiri, mencari-cari kegembiraan (sensation seeking), mudah tertarik terhadap sesuatu yang baru (exciteable).........." (Eysenck, 1997: 19).

Kemudian jika peneliti bandingkan dengan pernyataan Eysenck mengenai individu introvert, Eysenck (1997) menjelaskan bahwa seseorang dengan kecenderungan introvert memiliki karakteristik "tergantung suasana hati (moody), cemas (anxious), kaku (rigid), tenang (calm), pemalu (shy), lebih suka menyendiri (reserved), introspektif (thougtful), lebih menyukai buku/membaca daripada berbicara dengan orang lain dan menghadapi persoalan sehari-hari dengan serius, bersikap hati-hati dan menjaga jarak kecuali dengan teman dekatnya (careful), kurang mampu bersosialisasi (unsociable)........" (Eysenck, 1997: 19).

Maka berdasarkan kedua pernyataan tersebut diatas dapat diambil kesimpulan bahwa seseorang dengan kecenderungan ekstrovert akan memiliki tingkat komitmen lebih tinggi daripada seseorang dengan kecenderungan introvert. Hal tersebut dikarenakan seseorang dengan kecenderungan ekstrovert mampu lebih asertif, komunikatif, aktif serta pintar bersosialisasi dengan teman-temannya.

Subjek dengan kecenderungan kepribadian introvert yang memiliki komitmen organisasi tinggi

Terdapatnya subjek dengan kecenderungan kepribadian introvert akan tetapi memiliki tingkat komitmen organisasi tinggi, merupakan sesuatu hal yang menarik untuk di kaji lebih lanjut. Karena seperti yang telah peneliti uraikan sebelumnya, seseorang dengan tipe kepribadian cenderung introvert memiliki karakteristik tenang, pemalu, lebih suka menyendiri, introspektif, lebih menyukai buku/membaca daripada berbicara dengan orang lain dan menghadapi persoalan sehari-hari dengan serius, bersikap hati-hati dan menjaga jarak kecuali dengan teman dekatnya (Eysenck, 1997: 19).

Jika peneliti tinjau berdasarkan karakteristiknya tersebut, maka peneliti menyimpulkan bahwa seseorang dengan tipe kepribadian cenderung introvert akan memiliki tingkat komitmen terhadap organisasinya yang rendah. Hal tersebut dikarenakan ia akan mengalami kesulitan dalam hal bersosialisasi dan berinteraksi dengan teman-teman organisasinya, karena ia akan cenderung untuk menjaga jarak, menyendiri dan relatif lebih berpikir subjektif.

Akan tetapi, jika melihat pada data hasil uji statistik didapatkan hasil yang menunjukkan adanya subjek dengan kecenderungan introvert tapi memiliki tingkat komitmen organisasi tinggi sejumlah 8 orang atau sekitar $20 \%$. Berdasarkan hal itu, peneliti berasumsi bahwa terdapat suatu faktor lain yang lebih memiliki hubungan atau mempengaruhi sese- 
orang tersebut sehingga ia mampu untuk memiliki tingkat komitmen organisasi yang tinggi. Asumsi peneliti tersebut didukung oleh data hasil observasi terhadap beberapa subjek dengan kecenderungan introvert akan tetapi memiliki tingkat komitmen organisasi tinggi. Berdasarkan hasil observasi, peneliti mendapatkan gambaran bahwa subjek-subjek dengan kepribadian cenderung introvert akan tetapi memiliki tingkat komitmen organisasi tinggi memiliki suatu persamaan, antara lain: dalam melaksanakan tugas mereka relatif lebih tepat waktu meskipun dalam rapat mereka kurang mengeluarkan gagasan-gagasan, kebanyakan dari mereka menempati posisi yang tidak terlalu memerlukan proses interaksi dengan teman-teman satu organisasinya dan rata-rata dari mereka memiliki satu teman akrab yang selalu menemani mereka dalam satu organisasi serta beberapa dari mereka memiliki sifat kurang asertif yang begitu dominan.

Selain data hasil observasi, peneliti pun memiliki data hasil interview dengan beberapa subjek yang memiliki kecenderungan kepribadian introvert akan tetapi mempunyai tingkat komitmen organisasi tinggi. Beberapa alasan atau faktor yang menyebabkan mereka masih tetap bertahan dan memiliki tingkat komitmen tinggi terhadap OSIS diantaranya mereka merasa nyaman dengan posisi yang mereka tempati di dalam OSIS yaitu sebagai sekretaris atau bendahara.

Penempatan seseorang pada posisi dalam suatu organisasi yang sesuai dengan karakteristik dan skill yang dimilikinya ternyata dalam kasus ini berimplikasi positif, subjek yang seharusnya memiliki tingkat komitmen organisasi yang rendah karena ia seseorang dengan kecenderungan introvert, akan tetapi pada kasus ini dapat memiliki tingkat komitmen terhadap organisasi yang tinggi dikarenakan ia menempati posisi sebagai sekretaris atau bendahara yang tugasnya membutuhkan ketelitian, kecermatan dan kehati-hatian, akan tetapi tidak memerlukan banyak interaksi dengan orang lain. Hal tersebut tentunya cocok dengan karakteristik dari seseorang yang memiliki kecenderungan introvert karena sesuai dengan pernyataan Eysenck bahwa karakteristik seorang introvert adalah "tenang, pemalu, lebih suka menyendiri, introspektif, lebih menyukai buku/ membaca daripada berbicara dengan orang lain dan menghadapi persoalan sehari-hari dengan serius, bersikap hati-hati dan menjaga jarak ke- cuali dengan teman dekatnya" (Eysenck, 1997: 19).

Berdasarkan keterangan Eysenck pada paragraf di atas dapat peneliti simpulkan bahwa ketika seseorang yang memiliki karakteristik introspektif, suka membaca buku dan bersikap hati-hati, maka secara tidak langsung ia pun memiliki tingkat ketelitian dan daya konsentrasi yang lebih tinggi dari orang lain. Oleh karena itu, seseorang dengan karakteristik seperti itu akan merasa cocok ketika ditempatkan pada posisi atau jabatan yang membutuhkan tingkat ketelitian dan daya konsentrasi dalam menyelesaikan tugas-tugasnya seperti halnya mengatur, mengkalkulasi serta memperhitungkan keuangan ataupun juga mencatat, membuat surat atau proposal dan mengatur segala bentuk administrasi.

Faktor lain yang menyebabkan subjek dengan kecenderungan introvert namun mampu memiliki tingkat komitmen organisasi yang tinggi adalah adanya motivasi dari beberapa subjek untuk mengubah cara bergaul para pengurus OSIS agar lebih 'Islami' karena mereka berkeyakinan bahwa hal tersebut merupakan kewajiban bagi dirinnya selaku muslim dan mereka akan mendapatkan balasan berupa pahala pada hari akhir kelak. Pada faktor ini, peneliti lebih mencermati adanya suatu faktor belief (keyakinan) yang mampu merubah sikap dan tindakan subjek sehingga mereka tetap bertahan dan memiliki tingkat komitmen yang tinggi terhadap OSIS.

Linda K Stroh (2002) menyatakan bahwa sistem keyakinan kita merupakan sekumpulan teori dan ekspektasi (harapan) tentang mengapa dan bagaimana dunia itu bekerja; value (sistem nilai) merepresentasikan pemahaman utama kita tentang apa yang penting bagi kita. Hal ini menuntun kita untuk memiliki affects - kesukaan atau ketidaksukaan sebagai hasil evaluasi berdasarkan sistem keyakinan kita - tentang konflik. Untuk selanjutnya, keyakinan (belief) dan affects tersebut menyebabkan kita mengambil suatu langkah atau tindakan mengenai hal atau konflik yang terjadi.

Untuk lebih jelasnya, dapat dilihat dalam gambar berikut ini : 


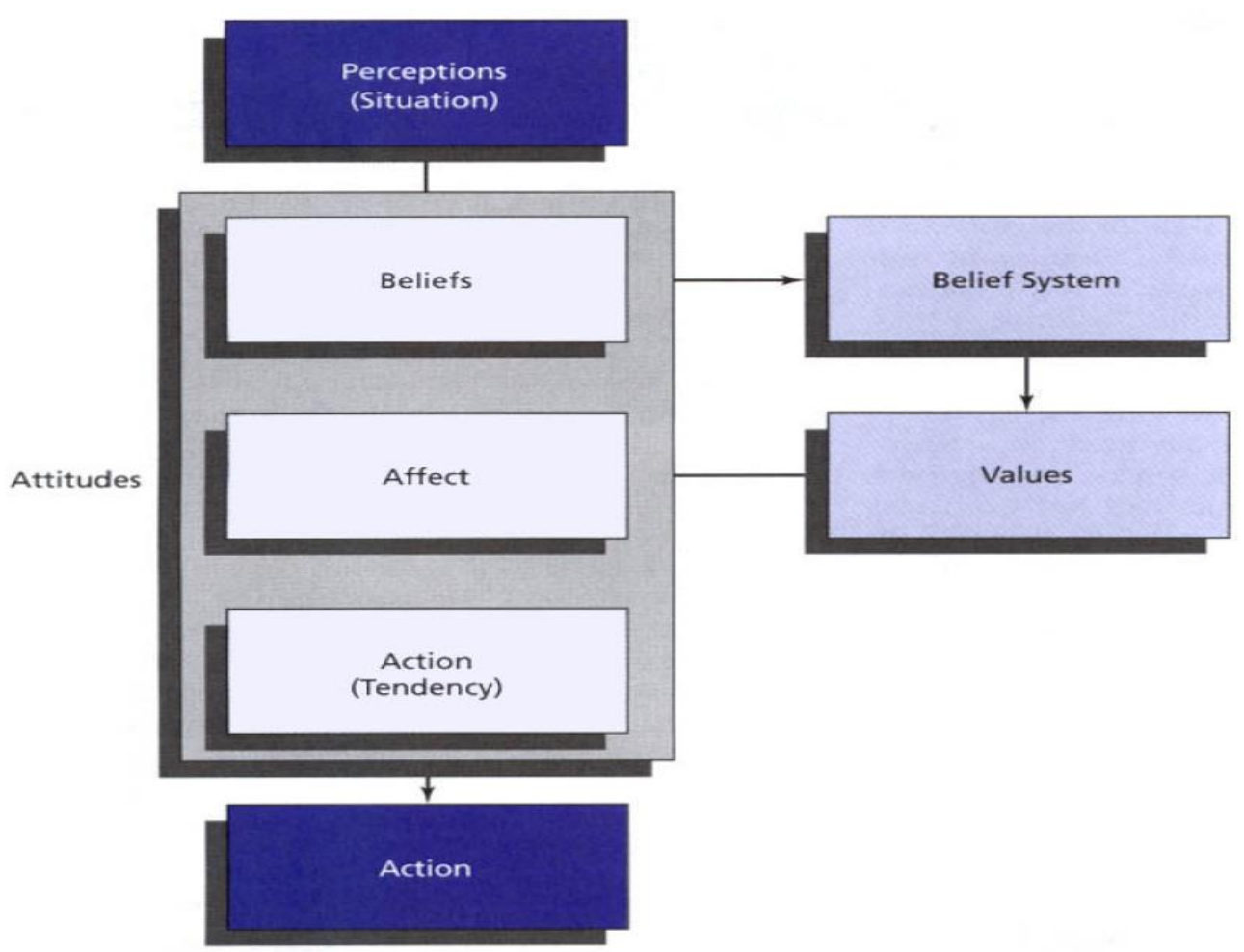

Gambar Skema alur Persepsi-Tindakan

Berdasarkan gambar tersebut, setidaknya dapat peneliti uraikan bagaimana seseorang dengan kecenderungan introvert mampu memiliki tingkat komitmen tinggi terhadap OSIS dikarenakan adanya faktor sistem keyakinan yang ia anut, hal itu terjadi ketika subjek mulai melihat dan mempersepsikan bagaimana cara pergaulan (situasi) di dalam OSIS, kemudian ia mulai membandingkan dengan sistem keyakinan yang ia miliki bahwa sebagai seorang muslim maka pergaulannya pun harus sesuai dengan sunnah Rasul (islami), setelah itu akan timbullah affect (suka-ketidaksukaan) akan kenyataan yang ia lihat tentang pergaulan di dalam OSIS. Pada titik ini, subjek mempunyai dua pilihan apakah ia akan tetap bertahan atau keluar dari OSIS, apabila situasi yang dihadapinya sesuai dengan keyakinannya maka ia akan tetap bertahan sebagai pengurus OSIS, akan tetapi apabila situasi yang dihadapinya tidak sesuai dengan keyakinannya maka ia akan keluar sebagai pengurus OSIS.

Sebelum subjek memutuskan pilihan mana yang akan ia pilih, sebelumnya ia akan kembali me-recall ingatannya tentang sistem keyakinan yang ia anut. Dalam hal ini, subjek memiliki keyakinan juga bahwa ia akan mendapatkan pahala atau balasan yang baik ketika ia mampu merubah pergaulan yang ada menjadi lebih islami. Berdasarkan keyakinannya tersebut maka subjek akan memiliki kecenderungan (tendency) untuk melakukan tindakan bahwa ia akan tetap bertahan di dalam OSIS dengan catatan ia akan berusaha untuk merubah gaya pergaulan di dalam OSIS menjadi lebih 'Islami'.

Subjek dengan kecenderungan kepribadian ekstrovert yang memiliki komitmen organisasi rendah

Fenomena yang menarik perhatian peneliti lainnya adalah adanya subjek dengan kecenderungan ekstrovert yang memiliki komitmen rendah. Berdasarkan hasil uji statistik didapatkan data sejumlah 5 orang pengurus yang memiliki kepribadian cenderung ekstrovert akan tetapi memiliiki komitmen organisasi yang rendah atau jika dipersentasekan sekitar $12.5 \%$.

Jika peneliti mengacu kepada teori Eysenck tentang karakteristik seseorang dengan kepribadian cenderung ekstrovert, maka seha- 
rusnya seseorang dengan kepribadian cenderung ekstrovert memiliki tingkat komitmen organisasi yang tinggi. Akan tetapi jika melihat pada fakta yang dihasilkan berdasarkan hasil uji statistik, ternyata ada pula sesseorang yang memiliki kecenderungan kepribadian ekstrovert akan tetapi memiliki tingkat komitmen organisasi yang rendah. Hal tersebut mememunculkan satu pertanyaan, "Sebenarnya faktor apa yang membuat seseorang dengan kepribadian cenderung ekstrovert akan tetapi memiliki tingkat komitmen organisasi yang rendah?".

Berdasarkan hasil observasi peneliti terhadap subjek dengan kepribadian ekstrovert akan tetapi memiliki tingkat organisasi yang rendah, didapatkan data bahwa subjek tersebut ternyata adalah seseorang yang cukup aktif dalam berorganisasi, karena ia mengikuti lebih dari satu organisasi selain OSIS, pada beberapa organisasi tersebut subjek memiliki posisi yang cukup penting seperti wakil ketua umum atau ketua bidang. Ketika rapat, subjek selalu berusaha untuk memberikan gagasan-gagasannya dan selalu berusaha untuk mengajukan namanya dalam kepanitian suatu kegiatan.

Selain data hasil observasi, peneliti pun mempunyai data hasil dari interview yang dilakukan kepada beberapa subjek, berdasarkan data tersebut diketahui beberapa faktor yang menyebabkan rendahnya tingkat komitmen subjek terhadap OSIS, salah satu faktor tersebut adalah tidak tercapainya esteem needs (kebutuhan harga diri) dari subjek. Hal tersebut peneliti ketahui, saat beberapa subjek mengungkapkan bahwa mereka merasa tidak terlalu penting dan tidak terlalu dibutuhkan di dalam OSIS. Mereka menilai bahwa di dalam OSIS sudah banyak orang yang lebih 'bisa' atau lebih pandai dari mereka, selain itu mereka pun merasa bahwa gagasan-gagasan yang mereka ajukan selalu ditolak dan ketika tergabung dalam suatu kepanitiaan mereka selalu di tempatkan pada posisi yang menurut mereka bukan posisi ideal bagi mereka. Oleh sebab itu, mereka lebih memilih untuk keluar atau fokus pada organisasi lain yang mereka anggap lebih membutuhkan subjek dan dapat menghargai kerja keras serta mampu menempatkan subjek pada posisi yang lebih penting seperti ketua KIR atau basket.

Berdasarkan data hasil interview di atas, peneliti berasumsi bahwa rendahnya tingkat komitmen seseorang dengan tipe kepribadian cenderung ekstrovert disebabkan karena subjek kalah dalam persaingan dengan teman satu organisasinya. Hal tersebut tentu saja menyebabkan tidak terpenuhinya kebutuhan akan harga diri (esteem needs) dari subjek sehingga membuat subjek lebih memilih untuk keluar dari OSIS atau pindah ke organisasi lain yang dapat memenuhi esteem needs nya.

Menurut Maslow, esteem needs merupakan salah satu dari 5 kebutuhan penting bagi seseorang sebelum mencapai kebutuhan aktualisasi diri. Esteem needs merupakan kebutuhan untuk dihargai, penghargaan positif, status dan pengakuan dari orang lain. Seseorang akan dapat mencapai kebutuhan ini apabila mereka sebelumnya telah dapat memenuhi 3 kebutuhan yang lainnya yaitu, basic psychological needs, safety needs dan affiliation needs (Stroh, 2002: $65)$.

Selanjutnya jika ditinjau dari sudut pandang perilaku organisasi (organizational-behavior) Stroh (2002: 64) menyatakan bahwa kebutuhan akan harga diri (esteem needs) khususnya atau kebutuhan (needs) secara umum merupakan salah satu aspek yang dapat membuat anggota organisasi termotivasi dan bersemangat dalam mengerjakan setiap tugas-tugas organisasinya. Apabila kebutuhan tersebut kurang atau tidak terpenuhi, maka tentu saja akan mengakibatkan pada penurunan kinerja anggota organisasi dan bahkan menyebabkan anggota tersebut keluar serta pindah ke organisasi lain yang dapat memenuhi esteem needs nya.

Faktor kedua yang menyebabkan seseorang dengan kecenderungan ekstrovert akan tetapi memiliki tingkat komitmen yang rendah adalah adanya tuntuan dari orang tua subjek, agar subjek lebih fokus kepada nilai akademik sekolahnya. Hal tersebut terungkap ketika peneliti mewawancarai subjek, lebih lanjut ia menyatakan bahwa orang tuanya mengharapkan agar subjek mendapatkan prestasi akademik yang bagus sehingga nantinya subjek dapat lulus dan masuk pada perguruan tinggi favorit. Subjek pun menyatakan bahwa ia mau tak mau harus berusaha mengikuti nasihat dari orang tuanya tersebut, karena mereka tahu hal tersebut merupakan sesuatu yang baik untuk dirinya dimasa mendatang.

Apabila peneliti mengacu kepada teori psikologi perkembangan Pappini, Rogman dan Anderson menyatakan bahwa subjek yang kini memasuki fase remaja tentunya merupakan hal yang wajar ketika ia lebih menuruti nasehat dari kedua orang tuanya. Pada masa remaja, 
terdapat sebuah proses yang disebut dengan attachment atau kedekatan dengan orang tua. Attachment yang kokoh dengan orang tua dapat menyangga remaja dari kecemasan dan potensi perasaan-perasaaan depresi atau tekanan emosional yang berkaitan dengan transisi dari masa anak-anak ke masa dewasa. Selain itu apabila remaja memiliki suatu attachment yang kokoh dengan kedua orang tuanya, mereka dapat memahami keluarga mereka sebagai keluarga yang kohesif dan mengeluhkan sedikit kecemasan sosial atau perasaan-perasaaan depresi (Santrock, 1995: 41).

Berdasarkan pernyataan Pappini, Rogman dan Anderson pada paragraf di atas, peneliti menyimpulkan bahwa penyebab subjek lebih memilih untuk menerima dan menuruti nasehat dari orang tuanya tersebut, dikarenakan subjek berusaha untuk mengurangi perasaan-perasaan depresi dan kecemasan sosialnya. Kecemasan sosial tersebut dapat timbul karena seseorang yang memasuki fase remaja belum memiliki tujuan dan identitas sosial yang cocok bagi dirinya.

Subjek dengan kecenderungan kepribadian introvert yang memiliki komitmen organisasi rendah

Data yang peneliti peroleh berdasarkan hasil uji statistik menyatakan bahwa terdapat subjek dengan tipe kepribadian cenderung introvert yang memiliki tingkat komitmen rendah sejumlah 15 orang. Hal tersebut tentu saja sesuai dengan penjelasan dan hipotesis peneliti sebelumnya, yakni seseorang dengan tipe kepribadian cenderung introvert akan cenderung pula memiliki tingkat komitmen organisasi yang rendah.

Rendahnya tingkat komitmen organisasi seseorang dengan tipe kepribadian cenderung introvert lebih disebabkan karena adanya hambatan pada interaksi dan komunikasi antara subjek dengan teman-teman organisasinya. Selain itu, dapat pula disebabkan oleh cara berpikir dari subjek yang terlalu subjektif dalam memandang suatu hal.

Namun, apabila berdasarkan hasil wawancara dengan beberapa subjek dengan tipe kepribadian cenderung introvert dan dengan tingkat komitmen organisasi yang rendah, peneliti mendapatkan data tambahan bahwa alasan subjek lebih memilih untuk keluar atau tidak aktif lagi dalam kepengurusan OSIS disebabkan oleh adanya perasaan inferiority dan terintimidasi. Perasaan tersebut muncul ketika subjek merasa tidak pantas menjabat sebagai pengurus OSIS karena ia bukanlah anak yang gaul dan tidak mempunyai kemampuan apaapa.

Berawal dari pemikiran tersebut, subjek pun pada akhirnya merasa terintimidasi oleh teman-teman satu organisasinya ketika subjek mendapatkan tuntutan dari teman-temannya tersebut agar dapat lebih aktif dan dapat berbaur dengan pengurus lainnya. Pada saat itu subjek pun akhirnya lebih memilih untuk tidak aktif dan keluar dari kepengurusan OSIS.

\section{SIMPULAN DAN SARAN}

\section{Simpulan}

Berdasarkan hasil yang diperoleh dari pengolahan data, pembahasan dan pengujian statistik, maka diperoleh kesimpulan yaitu sebagai berikut :

Terdapat hubungan positif antara tipe kepribadian dengan komitmen organisasi pada pengurus OSIS SMAN 2 Cimahi. Derajat hubungan antara kedua variabel menunjukkan korelasi sedang, artinya sebagian besar siswa yang memiliki tipe kepribadian ekstrovert memiliki tingkat komitmen organisasi yang tinggi, demikian pula sebaliknya, sebagian besar siswa yang memiliki tipe kepribadian introvert memiliki tingkat komitmen organisasi rendah.

Berdasarkan hasil analisis deskriptif, diperoleh 2 buah data yang menarik yaitu adanya subjek dengan tipe kepribadian cenderung ekstrovert yang memiliki tingkat komitmen organisasi rendah sebesar $12,5 \%$ dan adanya subjek dengan tipe kepribadian cenderung introvert yang memiliki tingkat komitmen organisasi tinggi sebesar $20 \%$.

Berdasarkan hasil observasi dan interview diperoleh kesimpulan bahwa terdapat faktor-faktor lain selain tipe kepribadian yang membuat seseorang dengan tipe kepribadian cenderung ekstrovert memiliki tingkat komitmen organisasi yang rendah yaitu tidak terpenuhinya kebutuhan akan harga diri (esteem needs) dan adanya tuntutan dari orang tua subjek untuk fokus pada prestasi akademik. Sedangkan faktor yang membuat seseorang dengan tipe kepribadian cenderung introvert mampu memiliki tingkat komitmen organisasi tinggi adalah adanya kesesuaian atau kecocokan antara posisi dalam organisasi dengan karakteristik subjek dan adanya suatu sistem keya- 
kinan (belief) yang membuat subjek mampu bertahan dan memiliki komitmen tinggi terhadap organisasinya.

\section{Saran}

Berdasarkan kesimpulan yang telah dipaparkan pada paragraf sebelumnya, berikut ini akan dipaparkan beberapa saran yang diharapkan dapat bermanfaat untuk menambah pengalaman dan sebagai bahan masukan atau pertimbangan, yaitu sebagai berikut :

Bagi penelitian selanjutnya, agar lebih dipertimbangkan lagi mengenai perlunya untuk menjaring data-data kualitatif lebih banyak lagi sebagai bahan untuk menunjang dan melengkapi hasil data kuantitatif, sehingga dapat menghasilkan analisis yang lebih akurat lagi. Selain itu, dikarenakan dalam penelitian ini terdapat kasus yang cukup menarik dan perlu dijawab serta diteliti kembali yaitu terdapat individu yang memiliki kecenderungan kepribadian introvert namun memiliki tingkat komitmen organisasi tinggi begitu pula sebaliknya terdapat siswa yang memiliki kecenderungan tipe kepribadian ekstrovert namun memiliki tingkat komitmen yang rendah. Maka dari itu peneliti memberi masukkan kepada peneliti lain untuk mencari atau menambah variabel lain yang diduga memiliki hubungan dan pengaruh yang lebih signifikan.

Sebagai bahan acuan dan pertimbangan bagi para pembina organisasi intra sekolah, alangkah baiknya jika dalam proses rekrutmen atau seleksi pengurus OSIS mulai memperhatikan karakteristik kepribadian para calon pengurusnya. Hal tersebut dikarenakan sesuai dengan hasil penelitian yang menunjukkan bahwa adanya hubungan antara tipe kepribadian dengan komitmen organisasi. Dengan mengetahui karakteristik kepribadian para calon pengurus OSIS yang baru, maka diharapkan agar dalam proses penempatannya (positioning) sesuai dengan karakteristik kepribadiannya. Mengadakan pembekalan serta training-training baik indoor maupun outdoor, hal tersebut tidak hanya menjadi tanggung jawab pembina organisasi saja akan tetapi pihak sekolah secara umum. Adapun tujuan dari pemberian training tersebut agar terciptanya rasa kebersamaan, saling memahami serta tumbuhnya chemistry di antara pengurus OSIS yang terpilih. Para pengurus yang memiliki tipe kepribadian introvert maupun ekstrovert diharapkan mampu berbaur dan menemukan kenyamanan dalam organisasi tersebut, sehingga menyebabkan peningkatan dalam komitmennya terhadap organisasi.

Di lingkungan lembaga pendidikan, hendaknya mulai dikembangkan paradigma "profesionalisme kerja", meskipun masih dalam ruang lingkup sekolah setingkat SMP atau SMA. Tujuannya antara lain adalah mendidik setiap siswa untuk membiasakan memiliki kultur profesionalisme yaitu seperti tepat waktu dalam mengerjakan sesuatu, bertanggung jawab, lebih mendahulukan kepentingan bersama daripada kepentingan pribadi dll. Hal tersebut bertujuan agar pengurus OSIS baik yang memiliki tipe kepribadian cenderung introvert maupun ekstrovert dapat lebih mengutamakan kepentingan organisasinya, sehingga secara tidak langsung menyebabkan peningkatan pada komitmen organisasi. 


\section{DAFTAR PUSTAKA}

Anik, Sri (2003). Analisis Pengaruh Komitmen Organisasi dan Keterlibatan Kerja terhadap Hubungan Antara Etika Kerja Islam dengan Sikap Perubahan Organisasi. diambil dari www.google.com

As Shafti, Kafti Muhammad Ali. (2003). Iltizam Membangun Komitmen Seorang Muslim. Jakarta : Gema Insani Press.

Azwar, S. (1999). Penyusunan Skala Psikologi. Yogyakarta : Pustaka Pelajar.

Azwar, S. (1999). Reliabilitas dan Validitas. Yogyakarta: Pustaka Pelajar.

Brown. B. Barbara. (2003). Employees' Organizational Commitment and Their Perception of Supervisors' Relations-Oriented and Task-Oriented Leadership Behaviors. Unpublihed doctoral dissertation, Faculty of the Virginia Polytechnic Institute and State University, Virginia.

Corr \& Mathew (ed). (2009). The Cambridge Handbook Of Personality Psychology. Cambridge: Cambridge University Press.

Departemen Agama Republik Indonesia. (1995). Al-Quran dan Terjemahnya. Jakarta: CV. Toha Putra Semarang

Dewi Sintania Lisna. (2008). Hubungan Tipe Kepribadian menurut H.J Eysenck dengan Perilaku Bullying pada Siswa Kelas Xl. Skripsi. Bandung : UIN

Eysenck, H.J. (1974). Dimensions of Personality. New Jersey : Transaction Publishers (1997). The Scientific of Human Nature. Denmark : Pergamon. (1986). Consensus and Controversy. London: The Falmer Press

Fakhrudin. Hakikat dan Tujuan Manusia Menurut Al-Ghazali. diambil dari www. google.com

Fakultas Psikologi UIN Sunan Gunung Djati. (2012). Panduan Penyusunan dan Penulisan Skripsi. Bandung
Friedenberg, Lisa. (1995). Psychological Testing Design, Analysis, and Use. Massachusetts: Allyn \& Bacon.

Guillford. J.P. 1959. Fundamental Statistic in Psychology and Education. New York: Mc Graw Hill Book Company

Hadi, Sutrisno. (1984). Metodologi Research: untuk Penulisan Paper, Skripsi, Thesis dan Disertasi. Yogyakarta: Yayasan Penerbitan Fakultas Psikologi UGM

id.wikipedia.org Organisasi Siswa Intra Sekolah. tersedia: 21 Maret 2012.

McCroskey \& Wahba. (2005). Temperament and Brain Systems as Predictors of Assertive Communication Traits. Virginia: West Virginia University

Millon \& Lerner. (2003). Handbook of Psychology Volume 5 Personality and Social Psychology. New Jersey: John Wiley \& Sons, Inc.

Mujib, Abdul. (2007). Kepribadian Dalam Psikologi Islam. Jakarta: Rajawali Press.

Muthuveloo. Rose. (2005). Typology of Organizational Commitment. American Journal of Applied Science

Nelson \& Cooper (ed). (2007). Positive Organization Behavior. London: Sage Publication Ltd.

Santrock, W, John. (1995). Life-Span Development. Dallas: University of Texas

Schultz, D. P. (1982). Organizational Commitment. New York : Macmillan Publishing.

Searle, Ann. (1999). Introducing Research and Data in Psychology: A Guide to Methods and Analysis Routledge Modular Psychology. London: Taylor \& Francis Routledge Publisher

Sopiah. (2008). Perilaku Organisasional. Malang: Andi.

Stroh. K. Linda, Northcraft. B. Gregory, Neale. A. Margaterth. (2002). Organizational 
Hubungan antara Tipe Kepribadian Menurut Eysenck dengan Komitmen Organisasi pada OSIS SMAN 2 Cimahi

(Asep Abdul Kadir, Fenti Hikmawati \& Witrin Gamayanti)

Behavior A management Challenge third edition. New Jersey: Lawrence Erlbaum Associates, Inc., Publisher.

Sudjana. (2002). Metode Satistika. Bandung: Tarsito.

Suhara, Uus. (29 Juli 2011). Wawancara Pribadi

Suryabrata, Sumadi. (1998). Pengembangan Alat Ukur Psikologis. Yogyakarta: Andi
Suryabrata, Sumadi. (1998). Psikologi Kepribadian. Jakarta: PT. Raja Grafindo Persada

Siegel, S. (1997). Statistik Nonparametrik untuk Ilmu-Ilmu Sosial. Jakarta: Gramedia Pustaka Utama.

UIN Sunan Gunung Djati. (2007). Pedoman Penulisan Skripsi, Tesis dan Disertasi. Bandung : Sunan Gunung Djati Press.

Yakan, Fathi. (2010). Komitmen Muslim Sejati. Solo : Era-Intermedia. 